\title{
Panicum maximum cv. Tanzânia: climate trends and regional pasture production in Brazil
}

\author{
J. R. M. Pezzopane*, P. M. Santos*, S. R. M. Evangelista†, C. Bosił, A. C. R. Cavalcante§, \\ G. M. Bettiol*, C. A. de Miranda GomideI and G. Q. Pellegrino \\ *Brazilian Agricultural Research Corporation, Embrapa Southeast Livestock, São Carlos, SP, Brazil, †Brazilian \\ Agricultural Research Corporation, Embrapa Agriculture Informatics, Campinas, SP, Brazil, łLuiz de Queiroz \\ College of Agriculture, University of São Paulo, Piracicaba, SP, Brazil, §Brazilian Agricultural Research \\ Corporation, Embrapa Goats and Sheep, Sobral, CE, Brazil, TBrazilian Agricultural Research Corporation, \\ Embrapa Dairy Cattle, Juiz de Fora, MG, Brazil
}

\begin{abstract}
Projected change in forage production under a range of climate scenarios is important for the evaluation of the impacts of global climate change on pasture-based livestock production systems in Brazil. We evaluated the effects of regional climate trends on Panicum maximum cv. Tanzânia production, predicted by agrometeorological model considering the sum of degree days and corrected by a water availability index. Data from Brazilian weather stations (1963-2009) were considered as the current climate (baseline), and future scenarios, based on contrasting scenarios in terms of increased temperature and atmospheric $\mathrm{CO}_{2}$ concentrations (high and low increases), were determined for 2013-2040 (2025 scenario) and for 20432070 (2055 scenario). Predicted baseline scenarios indicated that there are regional and seasonal variations in $P$. maximum production related to variation in temperature and water availability during the year. Production was lower in the Northeast region and higher in the rainforest area. Total annual production under future climate scenarios was predicted to increase by up to $20 \%$ for most of the Brazilian area, mainly due to temperature increase, according to each climate model and scenario evaluated. The highest increase in forage production is expected to be in the South, Southeast and Central-west areas of Brazil. In these regions, future climate scenarios will not lead to changes in the seasonal production, with larger increases in productivity during the summer. Climate risk is expected to decrease, as the probability of occurrence of low forage productions will be lower. Due to the predicted increase in temperature and decrease in rainfall in the Northeast area, P. maximum production is expected to decrease, mainly when considering scenarios based on the PRECIS model for the 2055 scenario.
\end{abstract}

Keywords: ETA model, PRECIS model, global climate changes, growing degree days, water balance

\section{Introduction}

Global temperature may increase by up to $4 \cdot 8^{\circ} \mathrm{C}$ until 2100, according to predictions from the Fifth Assessment Report (AR5) of the Intergovernmental Panel on Climate Change (IPCC, 2013). According to Calzadilla et al. (2013), global agricultural production is expected to decrease by $0.5 \%$ in the medium and $2.3 \%$ in the long term. Furthermore, the distribution of cropland is expected to change, implying likely modifications of production and international trade patterns (Calzadilla et al., 2013).

In Brazil, analysis of scenarios derived from the PRECIS (Providing Regional Climate for Impact Studies) regional climate modelling system suggests that there will be significant changes in rainfall, in addition to increased maximum and minimum temperature extremes (Marengo et al., 2009). Global climate changes may have great impacts on agriculture, which is responsible for $22 \%$ of the Brazilian gross national product (CEPEA, 2013). Adaptation of production systems and mitigation of greenhouse gas emissions are the main challenges presented by the effects of global climate changes on agriculture. The impacts of future

Correspondence to: J. R. M. Pezzopane, Brazilian Agricultural Research Corporation, Embrapa Southeast Livestock, PO Box 339, CEP 13560-970, São Carlos, SP, Brazil.

E-mail: jose.pezzopane@embrapa.br

Corrections added on 14 September 2016, after first online publication: The address in affiliation were previously incorrect and has been corrected in this version.

Received 5 November 2014; revised 28 January 2016 
climate trends on agriculture have been assessed by many research groups in Brazil, and mitigation actions have been proposed (Camargo, 2010; Zullo et al., 2011; Assad et al., 2013).

Beef and milk production in Brazil are mainly pasture based (Assis et al., 2005; ABIEC, 2013). There are around 160 million ha of pasture land in Brazil, which represents $48 \%$ of the agricultural area (IBGE, 2006). Cultivated tropical grasslands represent more than $60 \%$ of the total pasture area and are located mainly in the North, Southeast and Central-west regions of Brazil (IBGE, 2006). Most of the pasture area is cultivated under rainfed conditions, increasing the potential effect of weather conditions on forage production.

Climate risks associated with agricultural production may be assessed by agro-climatic zoning methods, which associate plant production with weather conditions through mechanistic or empirical agrometeorological models. These methods have been used to evaluate the impacts of global climate changes upon agriculture production (Zhang et al., 2007; Knox et al., 2010; Marin et al., 2013) but have not been applied to Brazilian pasture-based livestock production systems.

Projected changes in forage production, under a range of climate scenarios, are important for the evaluation of the impacts of global climate changes on pasture-based livestock production systems in Brazil. We therefore evaluated the effects of regional climate trends, based on downscaled outputs of two general circulation models (ETA and PRECIS), on tropical pasture production in Brazil, represented here by Panicum maximum cv. Tanzânia.

\section{Materials and methods}

The projected regional forage production of $P$. maximum cv. Tanzânia in Brazil was determined based on an empirical agrometeorological model for forage production predictions, observed climate data from Brazilian weather stations, and future climate scenarios based on outputs of downscaled global circulation models.

\section{Panicum maximum cv. Tanzânia forage production model}

The model used for prediction of $P$. maximum forage production was based on Pezzopane et al. (2012), initially developed for local conditions of the State of Sao Paulo and latter adapted for broader Brazilian conditions by the use of data from São Carlos, Sao Paulo state (SP), Piracicaba (SP), Juiz de Fora, Minas Gerais state (MG) and Sobral, Ceara state (CE), for parameterization (Figure 1). Location and climate characteristics of each place are presented in Table 1. Detailed data on herbage accumulation rate (HAR) from São Carlos,
SP, and Piracicaba, SP, can be found in Pezzopane et al. (2012). Data from Juiz de Fora, MG, and Sobral, CE, were obtained from rainfed and irrigated plots between 2009 and 2012. Plots were fertilized with $360 \mathrm{~kg} \mathrm{ha}^{-1}$ of nitrogen annually and cut every $30 \mathrm{~d}$.

Parameters of simple linear regressions between herbage accumulation rates of irrigated P. maximum (dependent variable) and mean daily degree days (DD) of 54 growing cycles were estimated by the least square means method.

Degree days were estimated according to Ometto (1981) by:

$$
\mathrm{DD}_{i}=\left(\frac{\mathrm{T}_{\max _{i}}+\mathrm{T} \min _{i}}{2}-\mathrm{Tb}\right) \quad \text { when } \mathrm{Tmin}>\mathrm{Tb}
$$

$$
\mathrm{DD}_{i}=\frac{\left(\operatorname{Tmax}_{i}-\mathrm{Tb}\right)^{2}}{2\left(\operatorname{Tmax}_{i}-\mathrm{Tmin}\right)} \quad \text { when } \mathrm{Tb}>\operatorname{Tmin}
$$

where $\left(\mathrm{T}_{\max }\right)$ is the maximum daily air temperature $\left({ }^{\circ} \mathrm{C}\right),\left(\operatorname{Tmin}_{i}\right)$ is the minimum daily air temperature, and $(\mathrm{Tb})$ is the base temperature.

We used a base temperature of $14.3^{\circ} \mathrm{C}$, estimated by the x-Intercept method (Arnold, 1959; Cruz et al., 2011; Moreno et al., 2014). A simple linear regression with mean daily temperature of each growing cycle (Tmean) as independent variable and HAR as dependent variable was determined (Figure 2; $\mathrm{HAR}=-151.5+10 \cdot 6 *$ Tmean; $P<0.001)$, and the base temperature was estimated by solving the equation for ' $x$ ' when ' $y$ ' equals zero (i.e. the temperature at which HAR equals zero).

Herbage accumulation rate, estimated based on mean daily degree days, was corrected by a water availability index (ARM) for predictions under rainfed conditions (Pezzopane et al., 2012). The ARM index was calculated by the ratio between actual soil water store (WSACT) and soil water holding capacity (WSMAX), estimated by the climatological water balance (Thornthwaite and Mather, 1955) for three soil water holding capacities: 40, 60 and $100 \mathrm{~mm}$. Climatological water balance was calculated based on potential evapotranspiration, estimated as described by Thornthwaite (1948), and real evapotranspiration, estimated by the 5-d sequential climatological water balance.

The forage production model was tested against independent data for P. maximum HAR under rainfed conditions obtained from 36 growing cycles in São Carlos, SP, Piracicaba, SP, and Juiz de Fora, MG. To evaluate the model's performance, we used the coefficient of determination $\left(R^{2}\right)$, the index of agreement developed by Willmott (1981) (d), the mean squared error of prediction (MSEP) and the relative error of prediction (E) (Addiscott and Whitmore, 1987). 
(a)

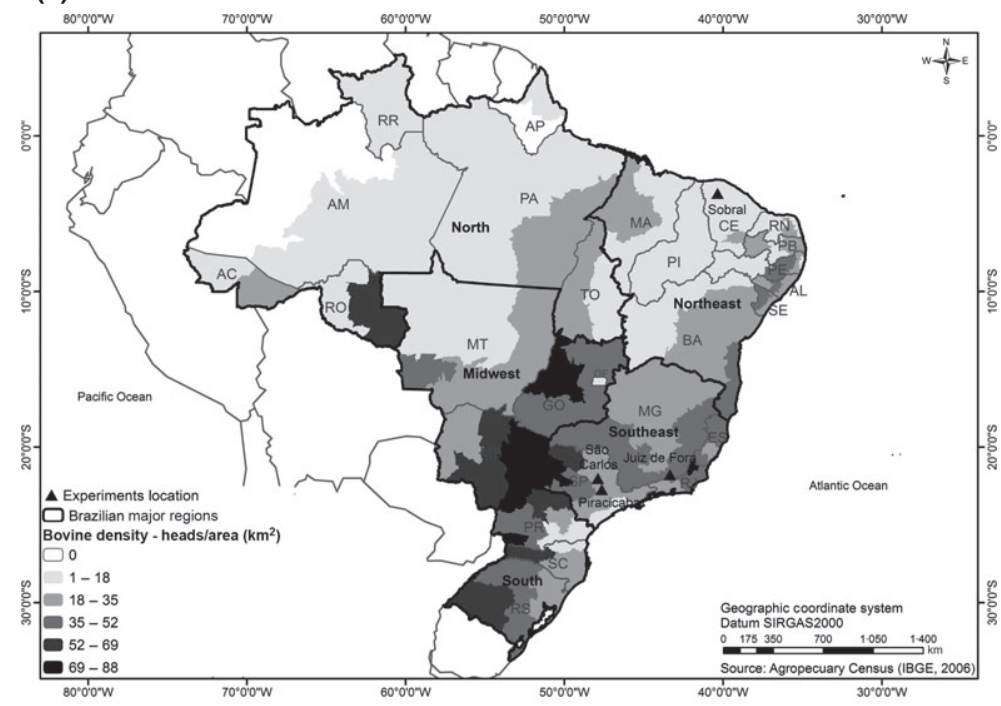

Figure I Location of experiments utilized for parameterization of the agrometeorological model of forage production, Brazilian administrative regions and bovine population density in the Brazilian territory (data of IBGE - Instituto Brasileiro de Geografia e Estatística, 2006) (a); location of weather stations from Agritempo system database and five representative areas in Brazil (South, MS-SP, GO, BA-MG and Zona da Mata do Nordeste), where livestock production is considered a relevant economic activity (b).

(b)

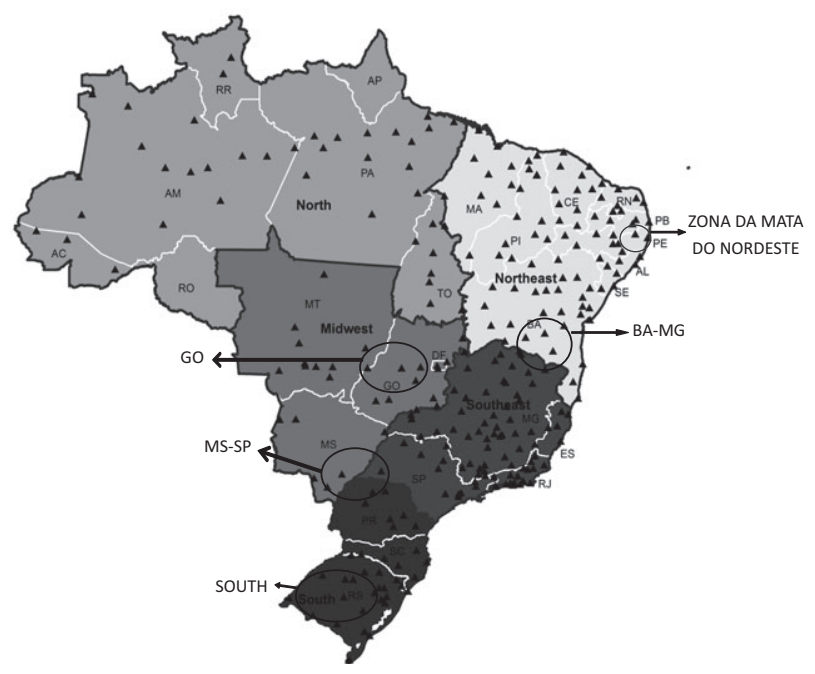

\section{Future climate scenarios}

We used future climate scenarios based on outputs of two downscaled global circulation models to project regional P. maximum production in Brazil. Details about the PRECIS modelling system and the ETACPTEC regional model may be seen in Marengo (2007), Marengo et al. (2009), Chou et al. (2012) and Marengo et al. (2012). Briefly, the PRECIS modelling system runs the Hadley Centre regional model HadRM3. The regional climate model HadRM3P has nineteen vertical levels and was run considering the lateral boundary conditions from the global climate model HadAM3P and a $50-\mathrm{km}$ resolution. The ETA-CPTEC regional model was adapted from the ETA model and allows integration of any time periods. Four combinations of boundary conditions from the Hadley Centre global climate model HadCM3 were used. HadCM3 was run considering a $2.5^{\circ}$ latitude $\times 3.75^{\circ}$ longitude resolution provided at a frequency of $6 \mathrm{~h}$. The ETA-CPTEC model nested to the HadCM3 global model had 38 vertical layers and was configured with a $40-\mathrm{km}$ horizontal resolution.

For each climate model, projections were made for an actual (1963 to 2009) and two future scenarios: 2012 to 2040 (2025 scenario) and 2042 to 2070 (2055 scenario). For the PRECIS modelling system, future scenarios were based on A2 (PRECIS A2) and 
Table I Location and climate characteristic of each site utilized in the parameterization of the agrometeorological model.

\begin{tabular}{lcccccc}
\hline Location & Latitude & Longitude & Altitude & $\begin{array}{c}\text { Average annual } \\
\text { temperature }\left({ }^{\circ} \mathbf{C}\right)\end{array}$ & $\begin{array}{c}\text { Total annual } \\
\text { rain }(\mathbf{m m})\end{array}$ & Hydric balance* $^{*}$ \\
\hline São Carlos & $21^{\circ} 57^{\prime} \mathrm{S}$ & $47^{\circ} 50^{\prime} \mathrm{W}$ & $860 \mathrm{~m}$. & $20 \cdot 5$ & 1392 & 440 \\
Piracicaba & $22^{\circ} 41^{\prime} \mathrm{S}$ & $47^{\circ} 38^{\prime} \mathrm{W}$ & $576 \mathrm{~m}$. & $21 \cdot 6$ & 1230 & 188 \\
Juiz de Fora & $21^{\circ} 33^{\prime} \mathrm{S}$ & $43^{\circ} 06^{\prime} \mathrm{W}$ & $410 \mathrm{~m}$. & $19 \cdot 3$ & 1644 & 765 \\
Sobral & $03^{\circ} 44^{\prime} \mathrm{S}$ & $40^{\circ} 20^{\prime} \mathrm{W}$ & $70 \mathrm{~m}$. & 26.6 & 960 & -696 \\
\hline
\end{tabular}

*Annual differences between rain and potential evapotranspiration.

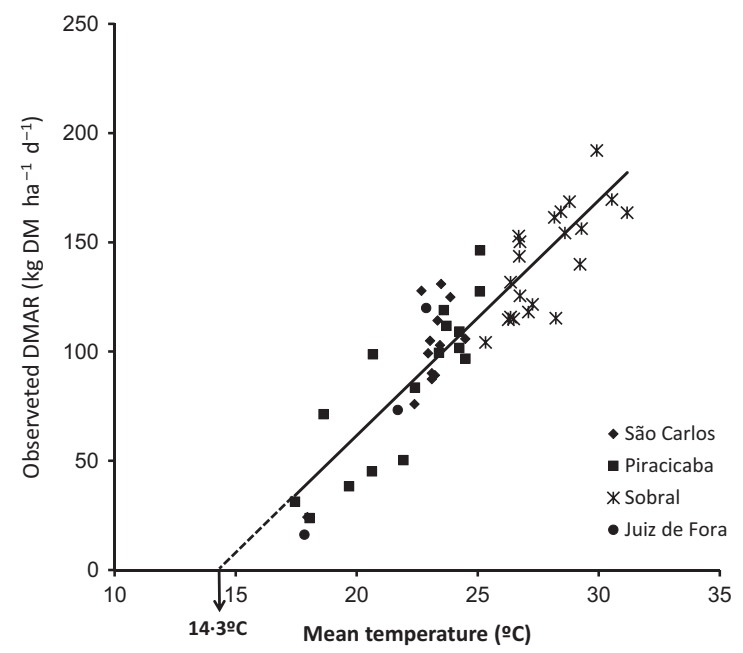

Figure 2 Determination of base temperature $(\mathrm{Tb})$ from the relationship between daily mean temperatures and herbage accumulation rate of Panicum maximum for the four location utilized in this study (São Carlos, SP; Piracicaba, SP; Sobral, CE; and Juiz de For a, MG).

B2 (PRECIS B2) scenarios described in the Special Report on Emissions Scenarios (Nakicenovic et al., 2000; Marengo, 2007; Marengo et al., 2009). For the ETACPTEC model, future scenarios were based on AlB scenario described on the Special Report on Emissions Scenarios (Nakicenovic et al., 2000) and were selected to represent results which displayed high (ETA High) and low (ETA - Low) sensitivity in global mean temperature response (Chou et al., 2012; Marengo et al., 2012).

A specific change factor for monthly maximum and minimum temperature and rainfall was estimated from data for actual and future climate scenarios and applied to weather stations' historical series to change the daily observed values (Marin et al., 2013). The following future climate scenarios were generated: PRECIS 2025 A2, PRECIS 2055 A2, PRECIS 2025 B2, PRECIS 2055 B2, ETA 2025 Low, ETA 2055 Low, ETA 2025 High, ETA 2055 High.

\section{Pasture production scenarios}

Daily observed data on temperature and rainfall for each climate scenario were used as input variables in the forage production model to predict the HAR of $P$. maximum. Future forage production scenarios were compared with the actual forage production scenario (baseline) predicted using data (maximum and minimum temperature and rainfall) from 285 Brazilian weather stations; maintained by INMET, INPE, ANA, EMBRAPA and other research institutes, universities and private companies; and systematized in the Agritempo system database (www.agritempo.gov.br) (Figure 1).

Forage production scenarios were generated for sandy, medium and clay texture soils, which were assumed to present a water holding capacity of 40, 60 and $100 \mathrm{~mm}$ respectively. Spatial interpolation of predicted actual annual forage production and of estimated percentage of change in annual forage production for each future climate scenario was carried out using kriging methods, with ArcGis 10.1 software tools.

Weather stations from five areas (South, MS-SP, GO, BA-MG and Zona da Mata do Nordeste), with high bovine population densities and where animal production was considered as an important economic activity, were selected for probabilistic studies on annual forage production and forage production seasonality (Figure 1). It is important to highlight that the meteorological stations of the GO area are located in the Cerrado biome, which represents $23.9 \%$ of the Brazilian territory (IBGE, 2004) and where the largest bovine population density is found (Figure la). Actual and predicted future climate characteristics of each area are presented in Table 2 .

\section{Results}

\section{Panicum maximum forage production model}

Forage production model for irrigated conditions, adapted from Pezzopane et al. (2012), was: 


$$
\mathrm{HARi}=10 \cdot 76 * \mathrm{DD}
$$

where HARi is the HAR of irrigated P. maximum ( $\mathrm{kg} \mathrm{DM} \mathrm{ha} \mathrm{h}^{-1} \mathrm{~d}^{-1}$ ), and DD is mean daily degree days $\left({ }^{\circ} \mathrm{C}\right.$.day).

The linear regression model fitted better to data from the adapted model $\left(R^{2}=0.79\right.$; Figure 3a) than to data from the original model $\left(R^{2}=0.73\right.$; Pezzopane et al., 2012). The adapted model also had a non-significant intercept $(P=0.9901$; Figure 3$)$ and a lower slope coefficient $(b=10 \cdot 76$; Figure 3$)$ than the original model $(a=-38.41$ and $b=18.70$; Pezzopane et al., 2012). Differences between the original and the adapted model are due to environmental conditions of the experiments. The adapted forage production model was generated from data obtained for a broader range of daily mean temperatures $\left(17.5\right.$ to $31.2^{\circ} \mathrm{C}$; Figure 2$)$ than the original model $\left(17.5\right.$ to $24.5^{\circ} \mathrm{C}$; Pezzopane et al., 2012). Furthermore, in the original model (Pezzopane et al., 2012), the regression equation already took into account the availability of soil water as an independent variable.

The ARM index (calculated by the ratio between actual soil water storage and soil water holding capacity) was used to correct predictions of HAR for rainfed areas. The model had a good performance when evaluated against an independent observed data set $\left(R^{2}=0.81, d=0.93, \operatorname{MSEP}=265.6\right.$ and $E=-19.58$; Figure $3 \mathrm{~b}$ ) and a slightly better coefficient of determination than the original parameterization $\left(R^{2}=0 \cdot 76\right.$, $d=0.93)$.

\section{Panicum maximum production in an actual climate scenario}

Predicted actual production of P. maximum on medium texture soils varied across Brazil due to local differences in climatic conditions (Figure 4). The same patterns of production were observed for sandy and clay texture soils (data not presented). The lowest levels of production $\left(<10000 \mathrm{~kg} \mathrm{DM} \mathrm{ha}{ }^{-1}\right.$ year $\left.^{-1}\right)$ were predicted for semiarid areas in Brazil's Northeast (states of Bahia, Piauí, Pernambuco and Paraíba). In these areas, mean annual rainfall is about $600 \mathrm{~mm}$ and there is great variability between years, resulting in low values for mean herbage mass production and also in low persistence of rainfed pastures of P. maximum. At present, native species from the Caatinga biome and exotic species that are well adapted to low water availability, e.g. Opuntia spp. and Cenchrus ciliaris, are the main plants used as forage in animal production systems in these areas at present (Santos et al., 2011).

The highest levels of production from P. maximum (more than $30000 \mathrm{~kg} \mathrm{DM} \mathrm{ha}^{-1}$ year $^{-1}$ ) were predicted for the North region of Brazil, where rainfall levels above $2200 \mathrm{~mm}$ and daily mean temperature above $26^{\circ} \mathrm{C}$ are observed (Alvares et al., 2014). Forage productions between 20000 and 30000 were predicted for some areas in the Atlantic Forest and Cerrado biomes (Figure 4), mainly due to high temperature levels during the rainy months.

Seasonal variation in daily HAR was observed across the country (Figure 5). For most areas of Brazil, the predicted HAR was higher between October and March (>80 kg DM ha $\left.{ }^{-1} \mathrm{~d}^{-1}\right)$ and lower between

Table 2 Actual (baseline) and future scenarios (PRECIS and ETA models) climate characteristic of five regions of Brazil utilized in the probabilistic studies (South, MS-SP, GO, BA-MG and Zona da Mata do Nordeste).

\begin{tabular}{|c|c|c|c|c|c|c|c|c|c|c|}
\hline \multirow{3}{*}{ Climate Scenario } & \multicolumn{10}{|c|}{ Region } \\
\hline & \multicolumn{2}{|c|}{ South } & \multicolumn{2}{|c|}{ MS-SP } & \multicolumn{2}{|c|}{ GO } & \multicolumn{2}{|c|}{ BA_MG } & \multicolumn{2}{|c|}{$\begin{array}{c}\text { Zona da Mata } \\
\text { Nordeste }\end{array}$} \\
\hline & $\begin{array}{l}\text { Annual } \\
\text { rain } \\
(\mathrm{mm})\end{array}$ & $\begin{array}{c}\text { Mean } \\
\text { temp. } \\
\left({ }^{\circ} \mathrm{C}\right)\end{array}$ & $\begin{array}{l}\text { Annual } \\
\text { rain } \\
(\mathrm{mm})\end{array}$ & $\begin{array}{l}\text { Mean } \\
\text { temp. } \\
\text { (C) }\end{array}$ & $\begin{array}{l}\text { Annual } \\
\text { rain } \\
(\mathrm{mm})\end{array}$ & $\begin{array}{c}\text { Mean } \\
\text { temp. } \\
\left({ }^{\circ} \mathrm{C}\right)\end{array}$ & $\begin{array}{l}\text { Annual } \\
\text { rain } \\
(\mathrm{mm})\end{array}$ & $\begin{array}{c}\text { Mean } \\
\text { temp. } \\
\left({ }^{\circ} \mathrm{C}\right)\end{array}$ & $\begin{array}{l}\text { Annual } \\
\text { rain } \\
(\mathrm{mm})\end{array}$ & $\begin{array}{c}\text { Mean } \\
\text { temp. }\left({ }^{\circ} \mathrm{C}\right)\end{array}$ \\
\hline Baseline & 1580 & $19 \cdot 5$ & 1472 & $22 \cdot 5$ & 1649 & $25 \cdot 1$ & 797 & $22 \cdot 5$ & 826 & $25 \cdot 0$ \\
\hline ETA 2025 Low & 1721 & $20 \cdot 1$ & 1539 & $23 \cdot 5$ & 1576 & $26 \cdot 2$ & 728 & $23 \cdot 3$ & 811 & $25 \cdot 8$ \\
\hline ETA 2055 Low & 1936 & $20 \cdot 9$ & 1619 & $24 \cdot 6$ & 1527 & $27 \cdot 3$ & 657 & $24 \cdot 3$ & 752 & $26 \cdot 7$ \\
\hline ETA 2025 High & 1682 & $21 \cdot 0$ & 1477 & $24 \cdot 3$ & 1537 & $27 \cdot 0$ & 668 & $24 \cdot 0$ & 828 & $26 \cdot 3$ \\
\hline ETA 2055 High & 1758 & $22 \cdot 0$ & 1448 & $26 \cdot 1$ & 1392 & $28 \cdot 8$ & 537 & $25 \cdot 2$ & 705 & $27 \cdot 4$ \\
\hline PRECIS 2025 B2 & 1623 & $20 \cdot 5$ & 1678 & $23 \cdot 6$ & 1731 & $26 \cdot 7$ & 640 & $23 \cdot 7$ & 524 & $26 \cdot 3$ \\
\hline PRECIS 2055 B2 & 1674 & $21 \cdot 2$ & 1809 & $24 \cdot 4$ & 1776 & $27 \cdot 7$ & 546 & $24 \cdot 4$ & 327 & $27 \cdot 1$ \\
\hline PRECIS 2025 A2 & 1598 & $21 \cdot 0$ & 1788 & $24 \cdot 1$ & 1901 & $27 \cdot 2$ & 689 & $24 \cdot 1$ & 512 & $26 \cdot 7$ \\
\hline PRECIS 2055 A2 & 1635 & $22 \cdot 0$ & 1985 & $25 \cdot 1$ & 2048 & $28 \cdot 5$ & 624 & $25 \cdot 1$ & 307 & $27 \cdot 8$ \\
\hline
\end{tabular}


April and September $\left(<20 \mathrm{~kg} \mathrm{DM} \mathrm{ha}{ }^{-1} \mathrm{~d}^{-1}\right)$, although some variations were observed between different areas.

In the Southeast and Central-west regions of Brazil, the predicted HAR of $P$. maximum increased from October onwards and reached its highest values in January (100-120 kg DM ha $\left.{ }^{-1} \mathrm{~d}^{-1}\right)$, and decreased again in May. In contrast, the HAR in the Northeast region of Brazil increased from January to May. The higher predicted HAR between October and March observed in the Central-west and North regions compared with the Southeast and South regions are due to higher temperature levels during the rainy period.

\section{Global climate changes and Panicum maximum productivity}

Regional climate scenarios generated by both PRECIS (Providing Regional Climates for Impacts Studies) and ETA-CPTEC (ETA-Centro de Previsão do Tempo e Estudos Climáticos) models are predicted to have a positive impact on the productivity of $P$. maximum in most of Brazil (Tables 3 and 4). When the PRECIS model was used to generate the 2025 future climate scenarios, predicted variation of forage production was positive for more than $75 \%$ of the Brazilian land area, whereas a decrease of around $10 \%$ of total annual forage production was predicted for less than $25 \%$ of the country (Table 3). An increase in the proportion of the Brazilian territory where forage production is predicted to decrease by more than 10\% was observed when the PRECIS model was used to generate the 2055 climate scenarios (Table 3).

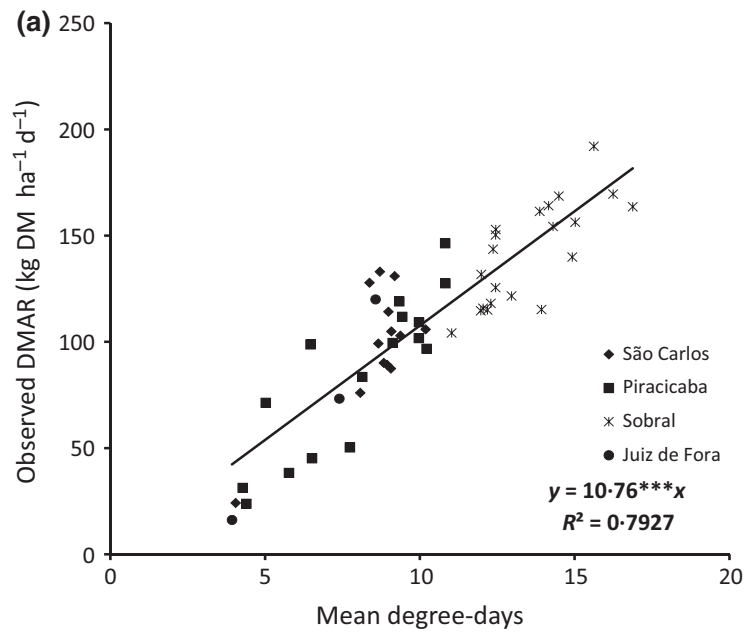

Increases of up to $10 \%$ for the low greenhouse gas emission scenarios (B2) and of $10-20 \%$ for the high greenhouse gas emission scenario (A2) are predicted for most of Brazil in the 2025 scenarios (Table 3). In the 2055 scenarios, forage production in most of Brazil is predicted to increase by $20-30 \%$ under a low greenhouse gas emission scenario and by more than $30 \%$ under the conditions of a high greenhouse gas emission scenario (Table 3 ).

Regional differences were observed in predicted changes of $P$. maximum forage production. Results for medium texture soils in the 2025 and 2055 future climate scenarios generated by the PRECIS model are presented in Figure 6. For low greenhouse gas emission scenarios in 2025, the South, Southeast and part of the Central-west regions of Brazil showed the highest positive changes in forage production (more than 20\% of actual production; Figure 6a) and in most of the Central-west, North and North-eastern coast of Brazil almost no change in forage production was predicted (between -10 and $+10 \%$ of actual production; Figure $6 \mathrm{a})$. On the other hand, around $20 \%$ decrease in forage production of the central area of Brazil's Northeast was predicted for this scenario. The same pattern was observed for high greenhouse gas emission scenarios in 2025, but areas where forage production is expected to increase in the Central-west region of Brazil were extended (Figure 6b).

The same regional tendencies of changes in forage production of $P$. maximum were observed for the 2055 scenarios, with a higher expected increase in forage production in the South and Southeast and a greater

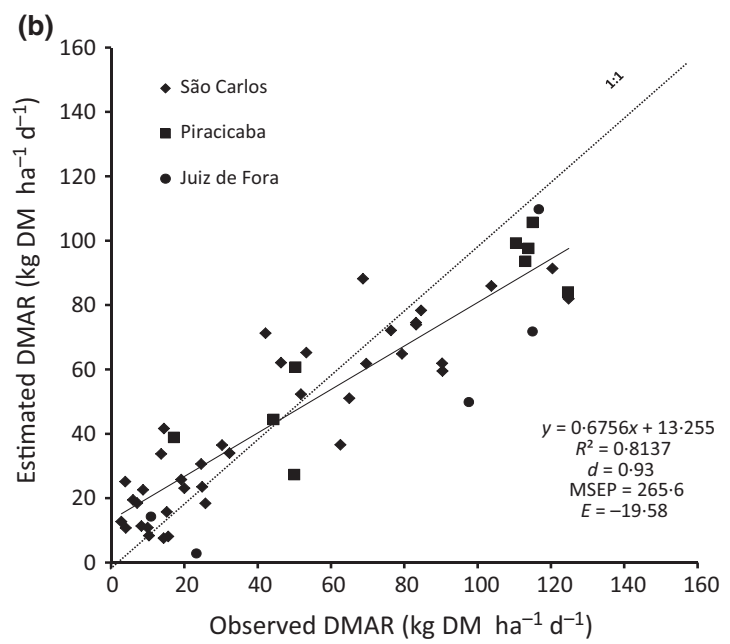

Figure 3 Regression equations between the mean degree days and dry matter accumulation rate (HAR) of Panicum maximum (a) and relationship between observed and estimated Panicum maximum HAR based on the degree days corrected by the WSACTMSMAX ratio (b). 


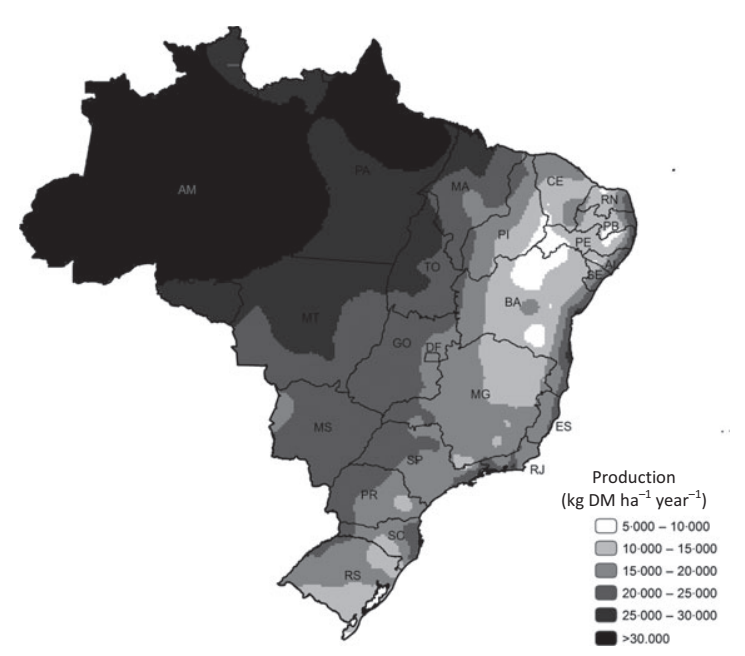

Figure 4 Predicted production of Panicum maximum on medium texture soils along the Brazilian territory.

expected decrease in forage production in part of the Brazilian Northeast area (Figure 6c and d).

In most of the Brazilian area, almost no change in P. maximum forage production $(0$ to $10 \%$ of actual productivity) was predicted for the 2025 climate scenarios generated by the ETA model (Table 4). Forage production is expected to increase by 10 to $20 \%$ for more than $40 \%$ of the Brazilian territory under the 2055 low temperature increases scenarios, based on the ETA model. For the high temperature increases scenarios, changes predicted for 2055 depend on soil texture class (Table 4). For sandy soils, a decrease of 20 to $30 \%$ in forage production is predicted for almost $30 \%$ of the area, while for medium and clay texture soils an increase of up to $20 \%$ is expected for most of the Brazilian territory.

Climate scenarios generated by the ETA model also determined regional differences in predicted changes of $P$. maximum forage production (Figure 6e, $\mathrm{f}, \mathrm{g}$ and h). Forage production is expected to increase in the South, Southeast and Central-west and to decrease in the Northeast region of Brazil, as also predicted for the PRECIS model's climate scenarios. Nevertheless, changes (increase or decrease in relation to the actual scenario) in forage production predicted by ETA models are higher than those predicted by the PRECIS model for the high greenhouse gas emission scenarios both in 2025 and 2055 .

\section{Climate risk associated with Panicum maximum production}

Climate risk associated with P. maximum production was analysed for five representative areas in Brazil, where livestock production is considered a relevant economic activity. Accumulated probability of $P$. maximum forage production as well as mean HAR per month for actual and future scenarios was determined (Figure 7a-e).

Climate risk is expected to decrease in the South, MS-SP and GO areas, as the probability of occurrence of low forage productions will be lower. Future climate scenarios had little impact upon seasonal forage production. Mean HAR is expected to continue lower during the winter (June to September) in these areas.

A higher annual forage production is expected in the South region due to a predicted increase in mean temperature and rainfall levels (Table 2). During the autumn (April-June), no variation is expected for HAR in future climate scenarios in this area. In the MS-SP area, an almost constant increase in HAR along the year is expected, while in the GO area higher increases in HAR are predicted during the summer and autumn due to a higher rainfall level, mainly for the 2055 scenario generated by the PRECIS model. In the GO area, no variation on HAR is expected during the spring, suggesting the necessity of adaptation of animal production systems. A decrease in forage production is expected in the BA-MG and Zona da Mata do Nordeste areas, mainly when future climate scenarios were generated by the PRECIS model (7 E and J). In these areas, soil water availability is expected to decrease due to a decrease in rainfall levels and an increase in temperature levels (Table 2). Cultivation of P. maximum will not be recommended in these areas if climate changes occur as predicted by the PRECIS model.

\section{Discussion}

The empirical model used to predict actual and future forage production of $P$. maximum had a good performance when evaluated against independent data and it predicted the seasonal forage production observed in many areas of Brazil (Figure 5). Tropical forage in Brazil switches from vigorous growth during the spring and summer to negligible growth during autumn and winter. In several previous studies, agrometeorological models have provided good predictive capacity of dry mass production of tropical grasses under rainfed conditions (Tonato et al., 2010; Cruz et al., 2011; Araujo et al., 2013 and Pezzopane et al., 2013). As in this work, these models take into account factors for temperature and soil water availability.

Empirical models have also been used to simulate production of subtropical forage grasses based on future climate scenarios in New Zealand (Baars et al., 1990; Zhang et al., 2007). One of the premises for the use of empirical models is that their application must 

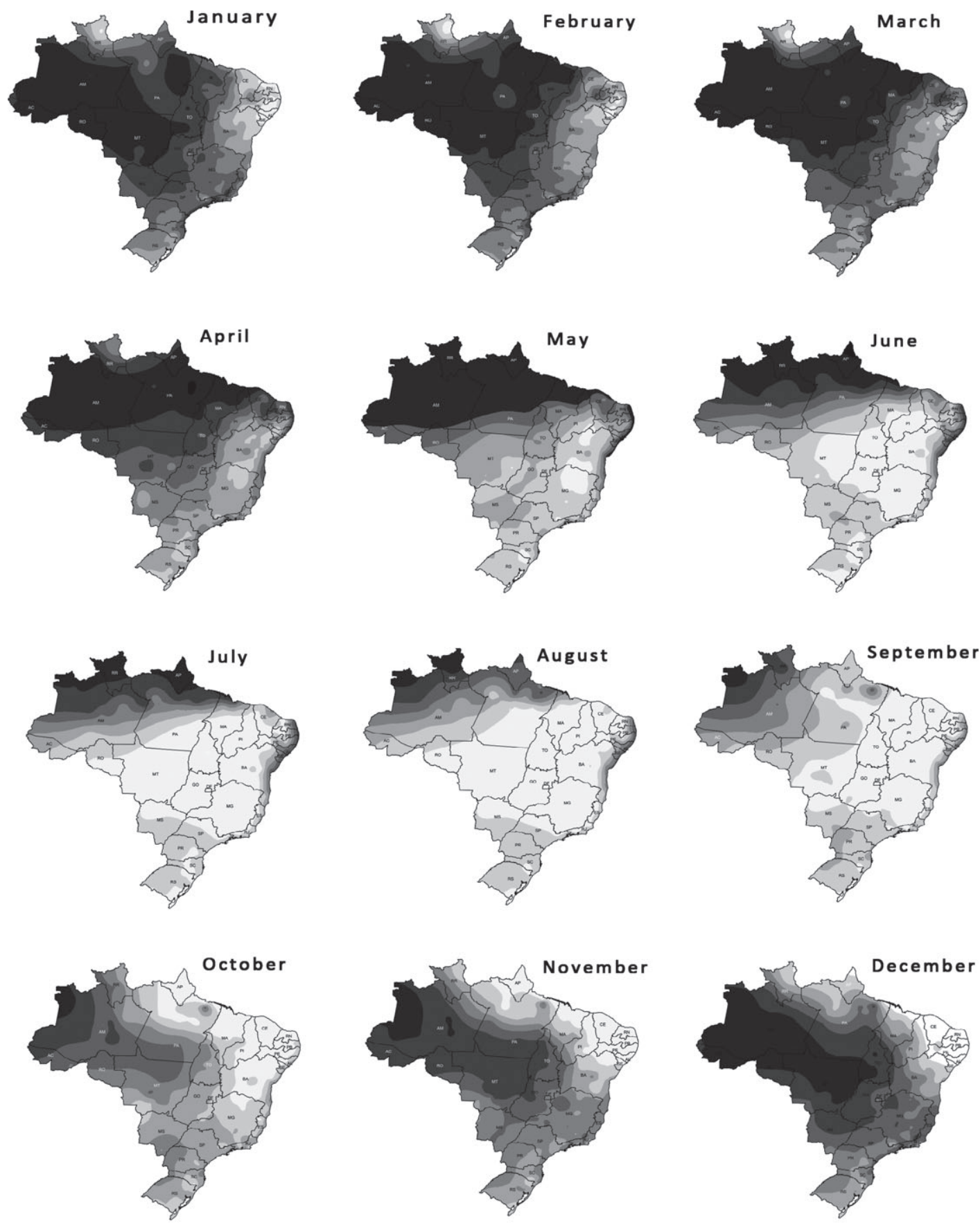

HAR (kg DM ha ${ }^{-1} \mathrm{~d}^{-1}$ )
$0-20$
$40-60$
$80-100$
$120-140$
$20-40$
$60-80$
$100-120$
$140-160$

Figure 5 Herbage accumulation rate (HAR) of Panicum maximum cv. Tanzania from January to December for the Brazilian territory on medium texture soils. 
Table 3 Classes of variation on annual production of Panicum maximum cv. Tanzania (\% of the baseline scenario production), for two future climate scenarios predicted by the PRECIS model for 2025 and 2055, for three soils types.

\begin{tabular}{|c|c|c|c|c|c|c|c|c|c|c|}
\hline \multirow[b]{3}{*}{ Soil type } & \multirow[b]{3}{*}{ Year } & \multirow{3}{*}{$\begin{array}{l}\text { Climate } \\
\text { scenario }\end{array}$} & \multicolumn{8}{|c|}{ Classes of variation on annual production (\%of baseline production) } \\
\hline & & & $<-30$ & -30 to -20 & -20 to -10 & -10 to 0 & 0 to 10 & 10 to 20 & 20 to 30 & $>30$ \\
\hline & & & \multicolumn{8}{|c|}{$\%$ of Brazilian territory } \\
\hline \multirow[t]{4}{*}{ Sandy texture } & 2025 & B2 & $0 \cdot 0$ & $1 \cdot 1$ & $6 \cdot 3$ & $16 \cdot 3$ & $38 \cdot 6$ & $35 \cdot 2$ & $2 \cdot 0$ & $0 \cdot 5$ \\
\hline & & A2 & $0 \cdot 0$ & $1 \cdot 1$ & $4 \cdot 6$ & $10 \cdot 5$ & $31 \cdot 3$ & $35 \cdot 6$ & 13.9 & $2 \cdot 8$ \\
\hline & 2055 & $\mathrm{~B} 2$ & $7 \cdot 6$ & $2 \cdot 1$ & $4 \cdot 2$ & $8 \cdot 4$ & $20 \cdot 3$ & $25 \cdot 5$ & $29 \cdot 5$ & $2 \cdot 5$ \\
\hline & & $\mathrm{A} 2$ & $7 \cdot 0$ & $1 \cdot 6$ & $2 \cdot 0$ & $4 \cdot 7$ & $20 \cdot 7$ & $14 \cdot 7$ & $21 \cdot 0$ & $28 \cdot 3$ \\
\hline \multirow[t]{4}{*}{ Medium texture } & 2025 & B2 & $0 \cdot 1$ & 1.9 & $7 \cdot 0$ & $15 \cdot 5$ & $41 \cdot 8$ & $31 \cdot 4$ & 1.9 & $0 \cdot 4$ \\
\hline & & $\mathrm{A} 2$ & $0 \cdot 1$ & $1 \cdot 6$ & $5 \cdot 0$ & $10 \cdot 3$ & $30 \cdot 8$ & $36 \cdot 4$ & $13 \cdot 0$ & $2 \cdot 6$ \\
\hline & 2055 & B2 & $7 \cdot 9$ & $2 \cdot 1$ & $4 \cdot 5$ & $8 \cdot 3$ & 19.9 & $26 \cdot 1$ & $29 \cdot 1$ & $2 \cdot 2$ \\
\hline & & A2 & $7 \cdot 4$ & 1.5 & $4 \cdot 6$ & $6 \cdot 3$ & $16 \cdot 9$ & $10 \cdot 2$ & $25 \cdot 9$ & $27 \cdot 2$ \\
\hline \multirow[t]{4}{*}{ Clay texture } & 2025 & B2 & $0 \cdot 1$ & $3 \cdot 2$ & $6 \cdot 9$ & $14 \cdot 3$ & $44 \cdot 1$ & $29 \cdot 3$ & $1 \cdot 8$ & $0 \cdot 2$ \\
\hline & & $\mathrm{A} 2$ & $0 \cdot 3$ & $2 \cdot 4$ & $5 \cdot 3$ & $9 \cdot 9$ & $31 \cdot 4$ & $35 \cdot 4$ & $12 \cdot 8$ & $2 \cdot 3$ \\
\hline & 2055 & B2 & $8 \cdot 5$ & $2 \cdot 0$ & $4 \cdot 4$ & $8 \cdot 9$ & $19 \cdot 0$ & $25 \cdot 6$ & $29 \cdot 5$ & $2 \cdot 1$ \\
\hline & & $\mathrm{A} 2$ & $8 \cdot 0$ & 1.4 & $4 \cdot 6$ & $6 \cdot 8$ & $16 \cdot 6$ & $9 \cdot 2$ & $25 \cdot 8$ & $27 \cdot 6$ \\
\hline
\end{tabular}

Table 4 Classes of variation on annual production of Panicum maximum cv. Tanzania (\% of the baseline scenario production), in two future climate scenarios predicted by the ETA model for 2025 and 2055, for three soils types.

\begin{tabular}{|c|c|c|c|c|c|c|c|c|c|c|}
\hline \multirow[b]{3}{*}{ Soil type } & \multirow[b]{3}{*}{ Year } & \multirow{3}{*}{$\begin{array}{l}\text { Climate } \\
\text { scenario }\end{array}$} & \multicolumn{8}{|c|}{ Classes of variation on annual production (\%of baseline production) } \\
\hline & & & $<-30$ & -30 to -20 & -20 to -10 & -10 to 0 & 0 to 10 & 10 to 20 & 20 to 30 & $>30$ \\
\hline & & & \multicolumn{8}{|c|}{$\%$ of Brazilian territory } \\
\hline \multirow[t]{4}{*}{ Sandy texture } & 2025 & Low & $0 \cdot 0$ & $0 \cdot 4$ & $3 \cdot 3$ & $20 \cdot 2$ & $59 \cdot 8$ & $13 \cdot 8$ & $1 \cdot 3$ & 1.2 \\
\hline & & High & $0 \cdot 2$ & $1 \cdot 3$ & $6 \cdot 0$ & $13 \cdot 8$ & $58 \cdot 5$ & $14 \cdot 2$ & $5 \cdot 1$ & $0 \cdot 9$ \\
\hline & 2055 & Low & $0 \cdot 3$ & $2 \cdot 1$ & $2 \cdot 0$ & $5 \cdot 5$ & $31 \cdot 6$ & $42 \cdot 4$ & $12 \cdot 5$ & $3 \cdot 6$ \\
\hline & & High & $17 \cdot 0$ & $29 \cdot 7$ & $2 \cdot 3$ & $20 \cdot 6$ & $3 \cdot 7$ & $7 \cdot 8$ & $7 \cdot 9$ & $11 \cdot 0$ \\
\hline \multirow[t]{4}{*}{ Medium texture } & 2025 & Low & $0 \cdot 0$ & $0 \cdot 3$ & $3 \cdot 5$ & $21 \cdot 0$ & $59 \cdot 5$ & $13 \cdot 7$ & $1 \cdot 1$ & $1 \cdot 0$ \\
\hline & & High & $0 \cdot 3$ & $2 \cdot 0$ & $5 \cdot 6$ & $13 \cdot 8$ & $58 \cdot 4$ & $14 \cdot 1$ & $5 \cdot 0$ & $0 \cdot 8$ \\
\hline & 2055 & Low & $0 \cdot 4$ & $2 \cdot 1$ & $2 \cdot 0$ & $5 \cdot 3$ & $29 \cdot 6$ & $44 \cdot 4$ & $13 \cdot 1$ & $3 \cdot 1$ \\
\hline & & High & $8 \cdot 1$ & $2 \cdot 4$ & $3 \cdot 4$ & $14 \cdot 3$ & $27 \cdot 3$ & $21 \cdot 4$ & $11 \cdot 0$ & $12 \cdot 0$ \\
\hline \multirow[t]{4}{*}{ Clay texture } & 2025 & Low & $0 \cdot 0$ & $0 \cdot 0$ & $3 \cdot 4$ & $22 \cdot 1$ & $59 \cdot 4$ & $14 \cdot 0$ & $0 \cdot 8$ & $0 \cdot 3$ \\
\hline & & High & $0 \cdot 4$ & $3 \cdot 7$ & $4 \cdot 2$ & $14 \cdot 2$ & $56 \cdot 6$ & $15 \cdot 3$ & $4 \cdot 8$ & $0 \cdot 6$ \\
\hline & 2055 & Low & $0 \cdot 9$ & $1 \cdot 7$ & $1 \cdot 8$ & $5 \cdot 1$ & $28 \cdot 6$ & $45 \cdot 0$ & $14 \cdot 0$ & $2 \cdot 8$ \\
\hline & & High & $9 \cdot 6$ & $2 \cdot 6$ & $6 \cdot 9$ & $25 \cdot 9$ & $24 \cdot 6$ & $17 \cdot 3$ & $5 \cdot 4$ & $7 \cdot 7$ \\
\hline
\end{tabular}

be performed in the same range as that of the independent variable for which it was parameterized. The forage production model used here was generated from data obtained with mean daily temperatures between 17.5 and $31.2^{\circ} \mathrm{C}$. This is within the range of temperatures observed, and of temperatures predicted by, the climate models used for the Brazilian territory (Marengo, 2007; Marengo et al., 2009, 2012; Chou et al., 2012; Alvares et al., 2014), indicating that it is suitable for forage production prediction in Brazil.

Cruz et al. (2011) and Pezzopane et al. (2012) observed good performance of empirical models when forage production predictions were corrected by a water availability index. Although the model used here does not consider the effect of higher vapour pressure deficit due to increasing temperature in climate change scenarios, the use of a water availability index, estimated by the climatological water balance, takes into account the effects of higher temperatures over water demands and, consequently, forage production.

On the other hand, there are limitations and uncertainties associated with the methods adopted by this study. Forage production was predicted by an 

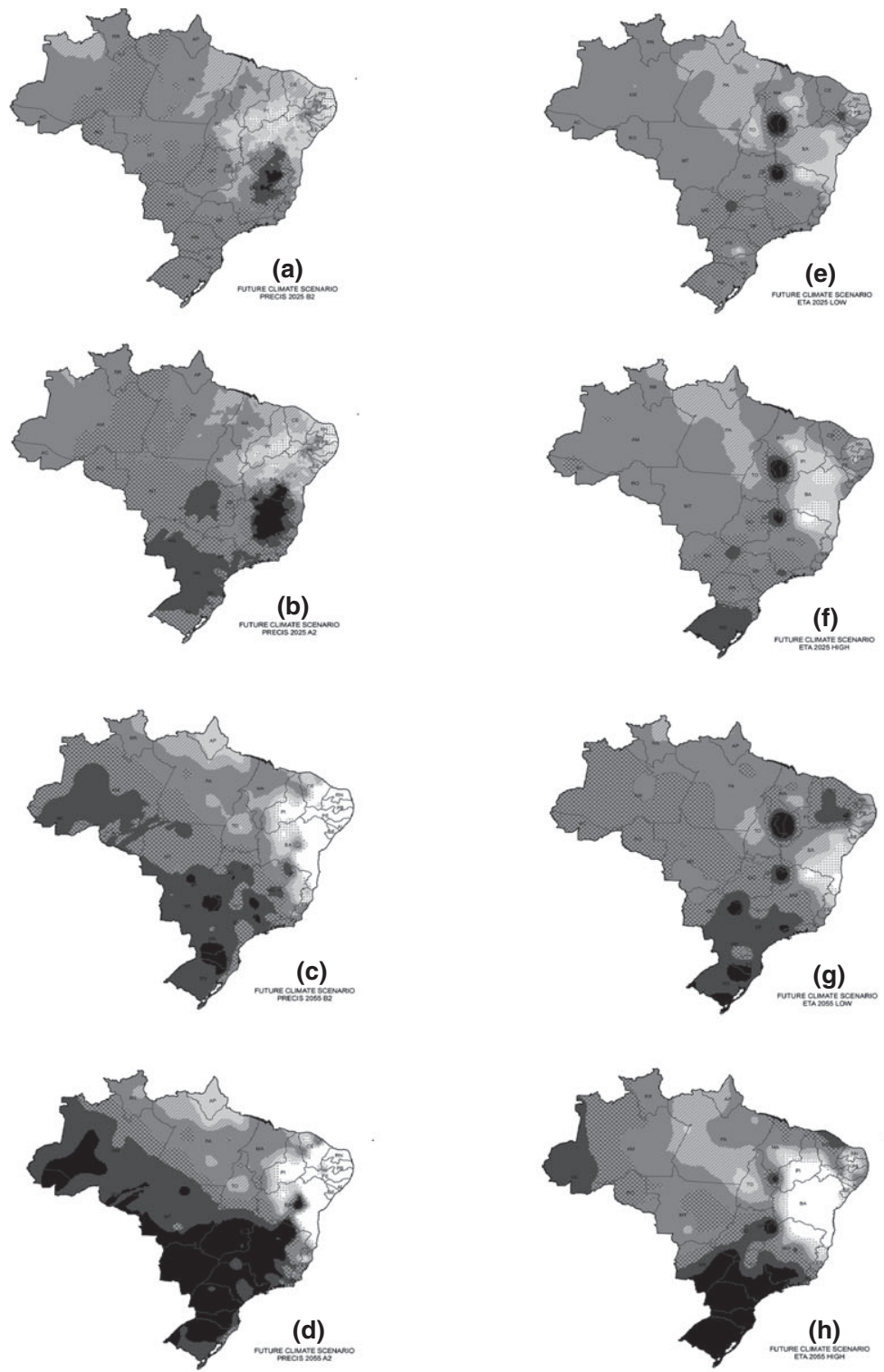

Change of forage production (\%)

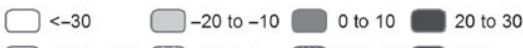

$\therefore-30$ to $-20 \square-10$ to $0 \quad 10$ to $20 \square>30$
Figure 6 Estimated change of annual Panicum maximum forage production in future climate scenarios predicted by the PRECIS model ( $a$ to $d$ ) and the ETA model (e to h) for the years 2025 and 2055, compared to the actual climate scenario for medium textured soils. empirical model that considers just temperature and water balance as a predictive factor. Although the data used for model parameterization were obtained in growth cycles with temperatures of up to $31.2^{\circ} \mathrm{C}$, there is some uncertainty about the performance of the models in temperatures close to or greater than this value. Unfortunately, no physiological studies about supra-optimal production temperature effects have been performed for tropical grasslands. Lara et al.
(2012), working with the CROPGRO Forage Perennial model, estimated $12,35,38$ and $50^{\circ} \mathrm{C}$ as parameters for base temperature, first optimum temperature, second optimum temperature and maximum (failure) temperature for vegetative development of $P$. maximum cv. Mombaça. A study of $\mathrm{Xu}$ et al. (2013) highlights that there is strong evidence of enhanced water-stressed $\mathrm{C}_{4}$ plants growth by an elevated $\mathrm{CO}_{2}$ concentration. The vulnerability of tropical-grassland-based 
(a)

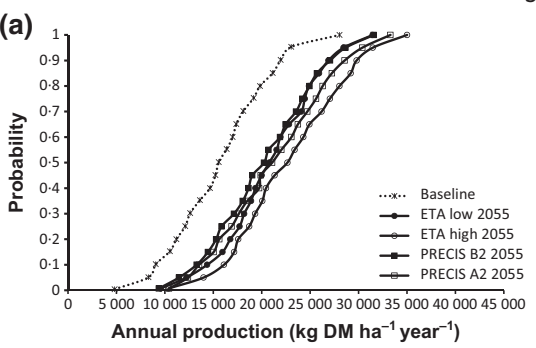

(b)

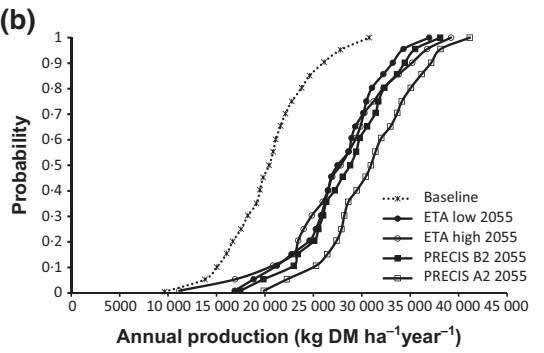

South

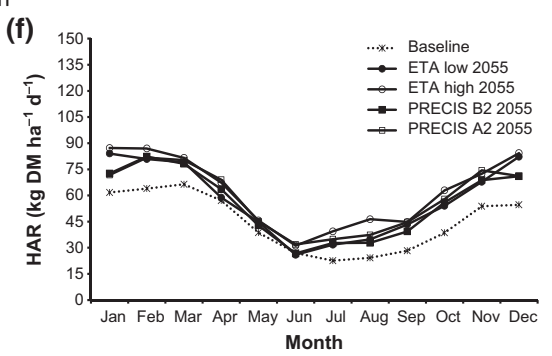

MS-SP

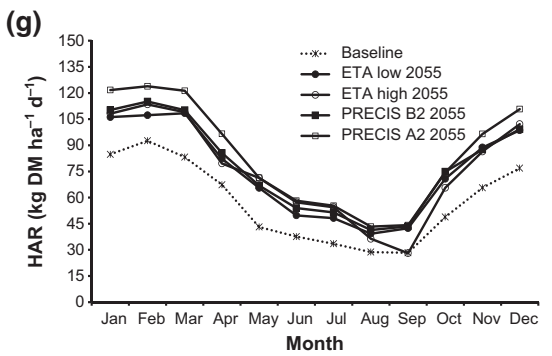

GO
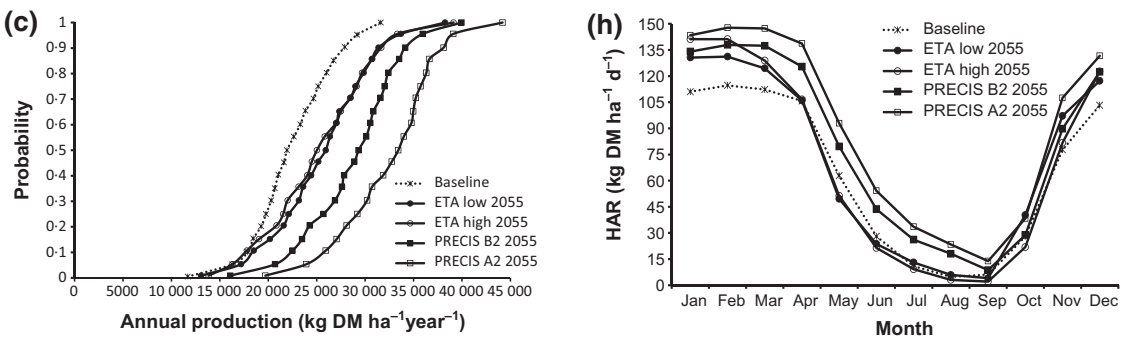

A-MG

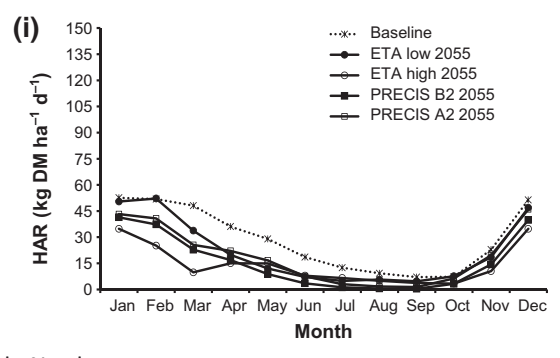

Zona da Mata do Nordeste
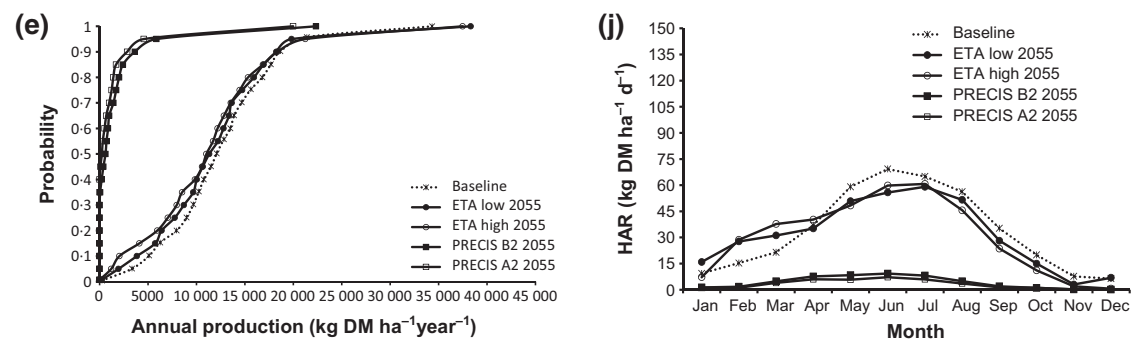

Figure 7 Accumulated probability of annual production (a to e) and monthly herbage accumulation rate ( $f$ to j) of Panicum maximum cv. Tanzânia in five representative areas of Brazil. 
animal production systems to climate changes would be better accessed by the use of mechanistic models. Although some mechanistic models have been parameterized for tropical forages (Pedreira et al., 2011; Lara et al., 2012; Araujo et al., 2013), parameters related to $\mathrm{CO}_{2}$ effects on plant processes have not yet been evaluated. Refinement of the simulations, including more factors, especially the atmospheric $\mathrm{CO}_{2}$ concentration, requires further experimentation.

Moreover, the forage production model used here does not consider the effect of physical and chemical properties of soil and of fertilization and pasture management on forage production. Data used for model parameterization were obtained from experiments fertilized with nitrogen at 200 to $360 \mathrm{~kg} \mathrm{~N}^{-1}$ year $^{-1}$ (Pezzopane et al., 2012). Future studies should be performed using mechanistic models such as those parameterized by Pedreira et al. (2011), Lara et al. (2012) and Araujo et al. (2013) to improve results by considering climate and soil characteristics together. Currently, the main limitations for a broader application of mechanistic models on future scenario studies seem to be the availability of basic and reliable data sets to support the understanding of processes, calibration of parameters, testing for input to models and the development and testing of model responses to extremes of rainfall and temperature and to elevated $\mathrm{CO}_{2}$ concentrations (Rivington and Koo, 2010).

Regional differences have been observed on predicted actual production of P. maximum. Low mean herbage accumulation rates during autumn and winter in the South region of Brazil are probably due to low temperature levels. This region is characterized by a rainy summer without a dry season, and climate is classified as Cfa according to the Koppen system (Alvares et al., 2014). Pezzopane et al. (2012) observed that the HAR of P. maximum pastures is close to zero when the mean daily temperature is below $17^{\circ} \mathrm{C}$. Low herbage accumulation rates of $P$. maximum pastures in the Southeast, Central-west and part of Northeast and North regions of Brazil are probably due to periods of water deficit. These areas are characterized by having rainy summers and dry winters, and their climate is classified as Aw according to the Koppen system (Alvares et al., 2014).

Regional climate scenarios generated by both PRECIS and ETA models are predicted to have a positive impact on future productivity of P. maximum in most of Brazil. An increase in mean temperature is predicted by both the PRECIS and ETA models for most of the Brazilian territory, with higher variations in the North (Marengo, 2007; Marengo et al., 2009, 2012; Chou et al., 2012). An increase between 1 and $2{ }^{\circ} \mathrm{C}$ for low temperature/greenhouse gas emission scenarios, and between 2 and $3^{\circ} \mathrm{C}$ for high temperature/ greenhouse gas emission scenarios are predicted for 2025. The same tendency is observed for 2055, when temperatures are expected to increase by between 2 and $4^{\circ} \mathrm{C}$ and between 3 and $5^{\circ} \mathrm{C}$ for the low and high greenhouse gas emission scenarios respectively. Temperature variation predicted by the PRECIS model is higher than that predicted by the ETA model, determining a greater expected increase in forage production in a more extensive area (Tables 3 and 4).

Both PRECIS and ETA models predicted a decrease in rainfall levels in the Northeast and North regions of Brazil and an increase in the South region (Marengo, 2007; Marengo et al., 2009, 2012; Chou et al., 2012). In the Central-west area, rainfall levels predicted by PRECIS are higher than those predicted by ETA models (Table 2), mainly during summer and autumn.

In those areas where the relation between rainfall levels and water demand is positive, an increase in forage production is predicted by future climate scenarios, as may be observed for the 2025 scenario in the North region of Brazil and for the 2055 scenario in the South, Southeast and part of Central-west areas.

Marin et al. (2013) predicted a mean increase of $22 \%$ in sugarcane productivity in the State of Sao Paulo (Southeast) between 2010 and 2100. Future climate scenarios in Marin et al. (2013) were generated by the PRECIS and CSIRO models. The results of our own study and also those of Marin et al. (2013) suggest a positive impact of global climate changes on $\mathrm{C}_{4}$ plant productivity.

Vulnerability of grassland-based livestock systems should not be assessed just by mean annual forage production, as variation between seasons and between years increases the system sensitivity. Sautier et al. (2013), studying the vulnerability of grassland-based livestock systems to climate changes in south-western France, predicted changes in seasonal boundaries, herbage production and production gaps between seasons with almost no impact on annual herbage production. In addition, climate impacts on grassland-based livestock systems depend on the strategies of animal and pasture management (Lurette et al., 2013). Climate risk is expected to decrease in the South, MS-SP and GO areas of Brazil, but little effect of future climate scenarios on seasonal forage production is expected. Thus, efforts for forage conservation between seasons, better control of the relationship between feed demand and feed production (production planning, cattle buying and selling, etc.) and adequate pasture management (fertilization, grazing control, irrigation, etc.) will become increasingly important for maintaining or improving animal production on these areas.

In parts of the Northeast and North regions, the increase in mean temperature predicted for the 2055 
scenarios will determine a greater water demand. As a decrease in rainfall levels is also expected for these areas (mainly under the scenarios predicted by the PRECIS model for the Northeast region in 2055) (Table 2), water availability tends to decrease (Tubiello et al., 2007; Assad et al., 2013) with a negative impact on future predicted forage production. Between the five areas selected by the presented study for further analyses, BA-MG and Zona da Mata do Nordeste were considered the most vulnerable to global climate changes. Nowadays, livestock production on these areas is largely based on tropical pasture use (mainly P. maximum and Brachiaria brizantha). The use of tropical forages that are recommended for semi-arid areas, like Cenchrus ciliaris and Andropogon guayanus, are considered important adaptation alternatives for the BA-MG and Zona da Mata do Nordeste areas.

\section{Conclusions}

Agrometeorological empirical models have a good predictive capacity for forage production of Panicum maximum. In Brazil, there are regional differences in P. maximum forage productivity capacity. For most of the Brazilian territory, a positive effect of future climate scenarios on P. maximum annual forage production is expected, mainly in the South, Southeast and Central-west regions of the country. A decrease in P. maximum forage production is expected for Brazil's Northeast. Seasonal production of $P$. maximum in Brazil occurs due to low temperatures or dry periods, and it is not expected to change under the conditions of future climate scenarios.

\section{References}

ABIEC - ASSOCIAÇÃo BRASIlEIRA DAS INDÚSTRIAS Exportadoras DE CARNe (2013) Estatística, balanço da pecuária (Statistics, balance of livestock). São Paulo, Brazil: ABIEC. http://www.abiec.org.br/index.asp. (accessed 20 January 2014).

Addiscott T.M. and Whitmore A.P. (1987) Computer simulation of changes in soil mineral nitrogen and crop nitrogen during autumn, winter and spring. The Journal of Agricultural Science, 109, 141-157.

Alvares C.A., S tape J.L., Sentelhas P.C., Gonçalves J.L., De M. and S parovek G. (2014) Koppen's climate classification map for Brazil. Meteorologische Zeitschrift, 23, $1-18$.

Araujo L.C., Santos P.M., Rodriguez D., Pezzopane J.R.M., Oliveir a P.P.A. and Cruz P.G. (2013) Simulating Guinea Grass production: empirical and mechanistic approaches. Agronomy Journal, 105, 61-69.

Arnold C.Y. (1959) The development and significance of the base temperature in a linear heat unit system.
Proceedings of the American Society for Horticultural Science, 74, 430-445.

Assad E.D., Martins S.C., Beltrão N.E.M. and Pinto H.S. (2013) Impacts of climate change on the agricultural zoning of climate risk for cotton cultivation in Brazil. Pesquisa Agropecuária Brasileira, 48, 1-8.

Assis A.G., Stock L.A., Campos O.F., Gomes A.T., Zoccal R. and Silva M.R. (2005) Sistemas de produção de leite no Brasil (Circular técnica 85) (Systems of milk production in Brazil (Technical Circular 85)). Juiz de Fora, Brazil: Embrapa.

BaArs J.A., Radcliffe J.E. and Rollo M.D. (1990) Climatic change effects on seasonal patterns of pasture production in New Zealand. Proceedings of the New Zealand Grassland Association, 51, 43-46.

Calzadilla A., Rehdanz K., Betts R., Falloon P., Wiltshire A. and Richard S.J.T. (2013) Climate change impacts on global agriculture. Climatic Change, 120, 357-374.

Camargo M.B.P. (2010) The impact of climatic variability and climate change on arabic coffee crop in Brazil. Bragantia, 69, 239-247.

CePea - Centro de Estudos Avançados em Economia Aplicada (2013) Relatório PIBAgro-Brasil (GDP agribusines - Brazil outlook). Piracicaba, Brazil: CEPEA. http.//cepea.esalq.usp.br/comunicacao/ cepea_pib_br_dez13.pdf. (accessed 20 January 2014).

Chou S.C., Marengo J.A., Lyra A.A., Sueiro G., Pesquero J.F., Alves L.M., Kay G., Betts R., Chagas D.J., Gomes J.L., Bustamante J.F. and Tavares P. (2012) Downscaling of South America present climate driven by 4-member HadCM3 runs. Climate Dynamics, 38, 635-653.

Cruz P.G., Santos P.M., Pezzopane J.R.M., Oliveira P.P.A. and ARAujo L.C. (2011) Modelos empíricos para estimar o acúmulo de matéria seca de capim-marandu com variáveis agrometeorológicas (Empirical models to estimate the accumulation of dry matter in Marandu palisade grass using agrometeorological variables). Pesquisa Agropecuária Brasileira, 46, 675-681.

ibGe - Instituto Brasileiro de Geografia e Estatístic a (2004) Mapas de Biomas e de Vegetação (Biomes and vegetation maps). Brasília, Brazil: IBGE. http://www.ibge.gov.br/home/presidencia/noticias/ 21052004biomashtml.shtm. (accessed 25 January 2016).

ibGE - Instituto Brasileiro de Geografia e E s t A Tís Tic a (2006) Séries estatísticas (Statistical series). Brasília, Brazil: IBGE. http://seriesestatisticas.ibge.gov.br/ lista_tema.aspx?op=0\&no=1. (accessed 23 November 2011).

IP C C (2013) Summary for policymakers. In: Stocker T.F., Qin D., Plattner G.K., Tignor M., Allen S.K., Boschung J., Nauels A., Xia Y., Bex V. and Midgley P.M. (eds) Climate change 2013: the physical science basis. Contribution of Working Group 1 to the fifth assessment report of the Intergovernmental Panel on Climate Change. pp. 3-29. Cambridge, UK: Cambridge University Press.

Knox J.W., Rodríguez Díaz J.A., Nixon D.J. and MKнWAnazi M. (2010) A preliminary assessment of 
climate change impacts on sugarcane in Swaziland. Agricultural Systems, 103, 63-72.

Lara M.A.S., Pedreira C.G.S., Boote K.J., Pedreira B.C., Moreno L.S.B. and Alderman P.D. (2012) Predicting growth of Panicum maximum: an adaptation of the CROPGRO - perennial forage model. Agronomy Journal, 104, 600-611.

Lurette A., Aubron C., Moulin C.-H. (2013) A Simple model to assess the sensitivity of grassland dairy system to scenarios of seasonal biomass production variability. Computers and Electronics in Agriculture, 93, 27-36.

Marengo J.A. (2007) Global climate change and its effects on biodiversity - Characterization of the current climate and definition of climate change for Brazilian territory along the XXI Century, 2nd edn. Brasília, Brazil: Ministerio do Meio Ambiente.

Marengo J.A., Jones R., Alves L.M. and Valverde M.C. (2009) Future change of temperature and precipitation extremes in South America as derived from the PRECIS regional climate modeling system. International Journal of Climatology, 29, 2241-2255.

Marengo J.A., Chou S.C., Kay G., Alves L.M., Pesquero J.F., Soares W.R., Santos D.C., Lyra A.A., Sueiro G., Betts R., Chagas D.J., Gomes J.L., Bustamante J.F. and Tavares P. (2012)

Development of regional future climate change scenarios in South America using the Eta CPTEC/ HadCM3 climate change projections: climatology and regional analyses for the Amazon, São Francisco and the Paraná River basins. Climate Dynamics, $\mathbf{3 8}$, 1829-1848.

Marin F.R., Jones J.W., Singels A., Royce F., Assad E.D., Pellegrino G.Q. and Justino F. (2013) Climate change impacts on sugarcane attainable yield in southern Brazil. Climatic Change, 117, 227-239.

Moreno L.S.B., Pedreira C.G.S., Boote K.J. and Alves R.R. (2014) Base temperature determination of tropical Panicum spp. grasses and its effects on degreeday-based models. Agricultural and Forest Meteorology, 186, 26-33.

Nakicenovic N., Alcamo J., Davis G., De Vries B., Fenhann J., Gaffin S., Gregory K., Grimber A., Jung T.Y., Kram T., La Rovere E.L., Michaelis L., Mori S., Morita T., Pepper W., Pitcher H., Price L., Riahi K., Roehrl A., Rogner H.-H., Sankovski A., Schlesinger M., Shukla P., Smith S., Swart R., Van Rooijen S., Victor N., Dadi Z. (2000) Special report on emissions scenarios: a special report of Working Group III of the Intergovernmental Panel on Climate Change. Cambridge, UK: Cambridge University Press.

О метто J.C. (1981) Bioclomatologia vegetal (Bioclimatology vegetable). São Paulo: Ceres. 440 p.

Pedreira B.C., Pedreira C.G.S., Boote K.J., Lara M.A.S. and Alderman P.D. (2011) Adapting the CROPGRO perennial forage model to predict growth of Brachiaria brizantha. Field Crops Research, 120, 370-379.

Pezzopane J.R.M., Santos P.M., Mendonça F.C. Araujo L.C. and Cruz P.G. (2012) Dry matter production of Tanzania grass as a function of agrometeorological variables. Pesquisa Agropecuária Brasileira, 47, 471-477.

Pezzopane J.R.M., Cruz P.G., Santos P.M., Bosi C. and Araujo L.C. (2013) Simple agrometeorological models for estimating Guineagrass yield in Southeast Brazil. International Journal of Biometeorology, 58, 1479 1487.

Rivington M. and Koo J. (2010). Climate change, agriculture and food security challenge program: report on the metaanalysis of crop modelling for climate change and food security. Available at: https://ccafs.cgiar.org/sites/default/files/ images/meta-analysis_of_crop_modelling_for_ccafs.pdf (accessed 27 May 2015).

Santos P.M., Voltolini T.V., Cavalcante A.C.R., Pezzopane J.R.M., Moura M.S.B., Silva T.G.F., Bettiol G.M. and Cruz P.G. (2011) Mudanças climáticas globais e a pecuária: cenários futuros para o Semiárido Brasileiro (Global climatic changes and animal production: future scenarios for the Brazilian Tropical Semiarid. Revista Brasileira de Geografia Física, 4, 1176-1196.

Sautier M., Martin-Clouaire R., Faivre R. and DURU M. (2013) Assessing climatic exposure of grassland-based livestock systems with seasonal-scale indicators. Climatic Change, 120, 341-355.

Thornthwaite C.W. (1948) An approach toward a rational classification of climate. Geographical Review, 38, 55-94.

Thornthinate C.W. and Mather J.R. (1955) The water balance. Publications in climatology. New Jersey, USA: Drexel Institute of Technology.

Tonato F., Barioni L.G., Pedreira C.G.S., Dantas O.D. and Malaquias J.V. (2010) Desenvolvimento de modelos preditores de acúmulo de forragem em pastagens tropicais (Development of forage accumulation prediction models in tropical pastures). Pesquisa Agropecuária Brasileira, 45, 522-529.

Tubiello F.N., Soussana J. and Howden S.M. (2007) Crop and pasture response to climate change. Proceedings of the National Academy of Science of the United States of America, 104, 19686-19690.

Willmotт C.J. (1981) On the validation of models. Physical Geography, 2, 184-194.

Xu Z., Shimizu H., Yagasaki Y., Ito S., Zeng Y. and Zно и G. (2013) Interative effects of elevated $\mathrm{CO}_{2}$, drought, and warming on plants. Journal of Plant Growth Regulation, 32, 692-707.

Zhang B., Valentine I. and Kemp P.D. (2007) Spatially explicit modelling of the impact of climate changes on pasture production in the North Island, New Zealand. Climatic Change, 84, 203-216.

Zullo J. Jr, Pinto H.S., Assad E.D. and de Ávila A.M.H. (2011) Potential for growing Arabica coffee in the extreme south of Brazil in a warmer world. Climatic Change, 109, 535-548.

Corrections added on 14 September 2016, after first online publication: Reference for Lurette et al 2013 was missing while reference for Silva et al 2012 should not have been included. Both of these references are corrected in this version. 